\title{
ENVIRONMENTAL CONDITIONS FOR SMME DEVELOPMENT IN A South African Province
}

\author{
D Mahadea \\ University of Kwazulu-Natal, Pietermaritzburg Campus \\ MK Pillay \\ Umgungundlovu F.E.T College, Pietermaritzburg
}

\begin{abstract}
The development of entrepreneurship is the focus of considerable policy interest in South Africa and many other countries. This is particularly in recognition of its contribution to economic growth, poverty alleviation and employment creation. In South Africa, various new strategies and institutions have recently been created with a view to empowering formerly disadvantaged members to enter the mainstream economy as entrepreneurs rather than job seekers. While the government directs considerable efforts to advancing Small, Medium and Micro Enterprises (SMMEs), certain environmental factors can favour or hinder the optimal development of these firms.

According to the Global Entrepreneurship Monitor (GEM) reports, the level of entrepreneurial activity in South Africa is rather low in relation to that in other countries at a similar level of development. This paper uses factor analysis to examine the internal and external environmental conditions influencing the development of small ventures on the basis of a survey conducted in Pietermaritzburg, the capital of the KZN province. The results indicate that three clusters constrain SMME development in Pietermaritzburg: management, finance and external environmental conditions. In the external set, rising crime levels, laws and regulations, and taxation are found to be significant constraints to the development of business firms.
\end{abstract}

JEL L26

\section{1}

\section{Introduction}

The promotion of Small, Medium and Micro Enterprises (SMMEs) is the focus of considerable interest in South Africa and many other countries. In its White Paper on National Strategy for the Development and Promotion of Small Business in South Africa, the government explicitly identified the promotion of SMMEs as a policy imperative for addressing the challenges of unemployment and poverty. SMMEs are an important source of jobs. They contribute significantly to the economic growth of any country and to advancing national and individual prosperity (Ntsika, 2000; World Bank, 2007). The transition from poverty to wealth in most nations has mainly been through private actors, farmers, investors or small and larger businesses. If countries, particularly those in Africa, are to emerge from poverty and unemployment, and create a more prosperous future, they will need more SMMEs and bigger businesses (Moss, 2007: 223). However, if this is to be achieved, entrepreneurs need an environment that is more conducive to starting up, operating and expanding their businesses. The Business Confidence Index for South Africa was at 92.6 in June 2008, marginally lower for Pietermaritzburg. Nevertheless, these are perhaps still encouraging signs for business. Further, South Africa registered an average real growth rate of 2.6 per cent over 1996-2000, while more recently the growth rate increased to around 5 per cent during the years 2004-2007 (SARB, 2008). 
Committed to promoting SMMEs, the government in South Africa has put in place various measures and strategies, such as the Small Enterprise Development Agency (SEDA), Khula, Ntiska, the National Empowerment Fund, the Umsombovu Youth Fund and the Accelerated and Shared Growth Initiative for South Africa (ASGISA) to fast-track the empowerment of formerly disadvantaged individuals into business entrepreneurship. Apart from financial assistance and training through various Sector Education and Training Authorities (SETAs), numerous fiscal incentives have been offered in the last few annual budgets with a view to augmenting the supply of effective entrepreneurship at the SMME level. Despite all these commendable efforts, the total early stage entrepreneurial activity (TEA), as also reflected by recent Global Entrepreneurship Monitor (GEM) reports, is rather low in South Africa in relation to that of other countries at a similar level of development.

South Africa's TEA rate actually decreased from 9.43 in 2001 to 5.29 in 2006, while, simultaneously, its ranking decreased from $14^{\text {th }}$ (out of 28 countries) to $30^{\text {th }}$ (out of 42 countries) over the same period. The TEA is a measure of the percentage of individuals between the ages of 18-64 years who are involved in starting or operating a new business up to 3.5 years. As fewer people (5.29 out 100) went into business in 2006 , relative to 2001 , when the figure was about 9.4, it seems that the level of entrepreneurial activity is not high enough to sustain South Africa's growth expectations and provide employment for an increasing number of school leavers (Herrington \& Maas, 2007).

Even with the provision of capital and training, regarded as critical inputs to business start-ups and expansions, there remains a deficit in the stock of entrepreneurial firms. This is partly shown in the low rates of participation in opportunity entrepreneurship by individuals in South Africa relative to an increasing necessity entrepreneurship sector. Necessity entrepreneurship comes about when individuals have no choice but to be "pushed" into business by the necessity to survive by earning a living, often in the informal economy, with little value-adding. However, entrepreneurial firms are driven by opportunity entrepreneurs who are alert to exploiting market gaps. SMMEs motivated by opportunity entrepreneurship have the potential to provide quality employment to their owners and others and to make a significant contribution to innovation and the country's GDP (Maas \& Herrington, 2006). In order to fully realise the growth potentials of an SMME economy, the internal and external environment should be supportive of entrepreneurial activities.

The question then arises as to what environmental factors influence or constrain the development of business ventures in a particular region. This paper thus examines whether environmental conditions are perceived to be favourable or detrimental to the growth of SMME entrepreneurship in Pietermaritzburg, the capital of South Africa's Kwazulu-Natal province. Environmental conditions refer to the broad range of conditions that affect the entrepreneurs and their businesses (Moss, 2007: 234).

The article consists of five main sections. The first deals with a review of the literature, briefly explaining business environmental conditions and highlighting some internal and external constraints; the second describes the research methodology; the third presents the findings, initially in a descriptive form with histograms and, thereafter, the factor analysis results. The fourth section presents a discussion of the results, followed by some policy suggestions.

\section{2}

\section{Business environmental conditions}

Businesses are neither independent nor completely isolated from the internal and external environment within which they function (Fry, Stoner \& Hattwick, 2001: 13). Firms operate in a real world and the decisions to exploit entrepreneurial opportunities are not made in a vacuum, but are influenced by the context in which they operate. The interaction of firms with their formal and informal institutions determines the environment in which the entrepreneurs operate at any point in time and in different places (North, 1994). The environment includes both "rules of the game", believed 
by social scientists to generate incentives for entrepreneurial activity, and the socioeconomic or political setting that determines legitimate or acceptable behaviour. Put simply, the environment refers to a broad range of conditions that affect entrepreneurs (Moss, 2007: 235). Changes in the environment can have positive or negative consequences for business growth. The business environmental conditions are particularly unfriendly throughout much of Africa (World Bank, 2006).

The environmental conditions are related to conditions both internal and external to the firm. Internal here refers to the characteristics or resources of the firm over which the entrepreneur has some measure of control, as well as his inherent entrepreneurial and managerial qualities. The external environmental conditions refer to the broad socio-economic, political and technological forces that originate outside the firm and cannot generally be altered by its actions. In other words, the firm may be influenced by changes within the external environment but cannot itself influence the environment. Forces in the external environment can help or hinder a firm's performance. The entrepreneur (individually) has almost no control over the external environment. However, the internal environment of a firm is shaped largely by the entrepreneur, who is the owner of the organisation and its key decision-maker.

As external factors change, it is expected that the alert entrepreneur would be pro-active in adapting to changes with suitable strategies so as not to miss out on business opportunities. However, not all entrepreneurs are sufficiently alert; some are content simply to operate a business as a going entity, as long as it generates a comfortable income. This can be a self-limiting choice for individuals with little ambition or motivation for onwards and upwards business development. Their firms are unlikely to experience rapid development, even when the external conditions are favourable, with an expanding GDP, increasing economic growth rates and a low rate of inflation or interest rate. It is usually firms whose entrepreneurs are high in need achievement, internal locus of control, risk-taking propensities, innovative tendencies, leadership and organisational abilities as well as managerial skills that tend to grow and develop fast in a world of changing environmental conditions (Storey, 1995; Cromie, 2000; Mahadea, 2001; Nieman, Hough $\&$ Nieuwenhuizen, 2003). These are internal driving factors brought to the firm mainly by the entrepreneur through his conduct of business. It is imperative for business development that individuals should have, or develop, the entrepreneurial attributes and management competencies against a background of changing environmental conditions.

\subsection{Internal environment}

\section{Access to finance}

Access to finance and the cost of financing are major obstacles to business start-ups and successful development of SMMEs in South Africa, as well as in developed and developing countries (Murphy 1996: 22; van der Merwe, 2003: 32). According to the Investment Climate Survey (2004:12), finance ranked among the top five constraints to business development in Sub-Saharan Africa. This is partly because financial institutions view many small firms as high-risk ventures with poor collateral. Lending to such firms means high administrative costs in relation to the size of the loans. The majority of small ventures raise finance through friends and family, or through informal lenders (Orford et al., 2003: 36). However, many entrepreneurs with a good track record, leadership skills and business plans experience no problem in accessing loans for business formations or expansions from financial institutions (Storey, 1995; Mahadea, 1997). The recent introduction of the National Credit Act (2007) may make it difficult for some firms to raise loans. However, as Marshall (1891) put it, ability always finds the necessary capital, and firms whose entrepreneurs are "dull" are by this fact alone restricted in their growth and development (Penrose, 2004: 36).

While increased financial support is necessary, what is more important is the ability to manage finances and keep proper records (Orford et al., 2003: 34). Given the centrality of cash flow to the survival of a business, proficiency in financial administration can reduce business failure. Ability to handle finances therefore becomes a 
prerequisite for business growth and expansion (Orford et al., 2003: 46).

\section{Human resource and management skills}

A firm would not exist if it did not have productive human inputs and a product that answers customer needs. It is the entrepreneur's responsibility to hire and manage labour and other resources within the firm. However, recruitment and retention of labour are affected by internal and external factors. Internally, if the firm is already operating near full capacity, increase in demand for the firm's products may necessitate additional labour. Although internal conditions necessitate the hire of additional manpower, the intricacies of the labour laws, such as Labour Relations, Employment Equity and Minimum Wage Regulations, may prevent employers from hiring additional labour. Such stringent legislation, which imposes labour market rigidities, robs the market of its flexibility, making hiring or firing too costly. When there is a shortage of skilled people, retention of labour is also a problem, as skilled workers often hop from one firm to another in response to incentives that could range from higher salaries to better benefits. Skills shortages thus make the recruitment process for quality labour more difficult, time consuming and expensive.

In today's competitive and changing business environment, it is not enough to have just the technical understanding of how to start a venture. The skills needed for initiating a business are different from those needed in managing it to a successful market growth stage. An entrepreneur who successfully starts a business may not necessarily be a good manager. This is a serious limitation to business development in South Africa, even at the micro level, where only about 4 per cent employ labour (GEM, 2005). Achieving growth carries further risks and entails tolerance of ambiguity. However, many SMME entrepreneurs fear the prospect of taking risks beyond the security of the comfort zone. Some are unable to take decisive action and are apprehensive of losing control over their business. Many entrepreneurs, lacking the self-confidence or tenacity to push an innovative idea, avoid financial risk and thus miss out on opportunities, even when the changing external environment is conducive to business growth. The presence, or lack of this entrepreneurial perspective, is exhibited inside the firm, in terms of its management strategies and organisational processes in place to adapt to change and survival.

Research indicates that the performance of SMMEs, and in effect, of any other organisation, is related, inter alia, to the education, training, management skills and experience of their entrepreneurs and managers, as well as the quality of their labour. An entrepreneur or manager who is well-educated, trained, experienced and skilled in various functional areas of management and marketing can perform better than another who is less talented. Consolidating research in various countries, Storey (1995) succinctly identifies three main factors influencing the growth of firms: background or resources of the entrepreneurs, the nature of the firm itself, and strategic decisions taken by the entrepreneurs as owner-managers in the firm. However, according to the GEM report (2006), the managerial and entrepreneurial skills necessary for SMME development are lacking in South Africa. Many South Africans thus lack the mindset and ingenuity to become high valueadding entrepreneurs in the short-term.

\section{Innovation and technology}

All businesses, regardless of their size, need to innovate and adopt new ideas and practices to satisfy the changing needs of the market in a global environment. Outcomes of innovation include: introducing new products or services in new and existing markets, developing new organisational structures competing in new ways; and using new production functions and technology in creative ways to service customer needs (Schumpeter, 1942; Casson, 2003). Although the utilisation of modern and digital technology can be a source of competitive advantage, some conservative entrepreneurs often view information technology as extremely expensive and may still prefer the conventional way of doing business. Such a myopic view ultimately constrains the growth prospects, as the firm is likely to miss out on opportunities in 
the changing environment. Indeed, according to the recent GEM study, 60 per cent of the surveyed entrepreneurs reported making no use of new technologies. However, emerging entrepreneurs were found to be generally more optimistic about technologies than were older businesses (GEM, 2006: 34).

\subsection{External environment}

The external environment relates to factors outside the firm over which the entrepreneur has little control. These include legal restrictions, such as requiring multiple licences to start a business, lack of property protection (the state can seize the private entrepreneur's assets and distribute them possibly to comrades or war veterans, making value-adding highly risky under conditions of low trust), excessive regulations and red tape, socio-economic conditions, such as high inflation and crime rates, availability or reliability of infrastructure services, including power, roads, transport services, information and communication technologies, and other exigencies. These environmental factors make running a business prohibitively onerous and raise the transaction costs. Investment climate surveys suggest that, compared with other developing country regions, Sub-Saharan Africa is a high-cost, high-risk place to do business. Overall, doing business in Africa costs about 20 per cent to 40 per cent more than in other developing country regions. These "obstructions" scare away foreign investors and dampen the zeal of domestic entrepreneurs for investing. They may also force many small entrepreneurs into the informal sector or emigration to other safer countries where the climate is more receptive to entrepreneurship, thus resulting in less investment, less growth and higher poverty (Gnyawali \& Fogel,1994: 46; World Bank, 2005, 2006). Adverse economic conditions, such as high interest rates, balance of payments deficits and unemployment, can also affect business adversely (Fry et al., 2001: 165).

\section{Taxation}

High tax rates and complex tax administration are constraints to enterprise development and can force firms to operate in the "grey" economy, where the pay-off from productive and nonproductive activities can be high, with possible tax evasion or avoidance.

Figure 1

Annual cost of tax compliance as a percentage of turnover

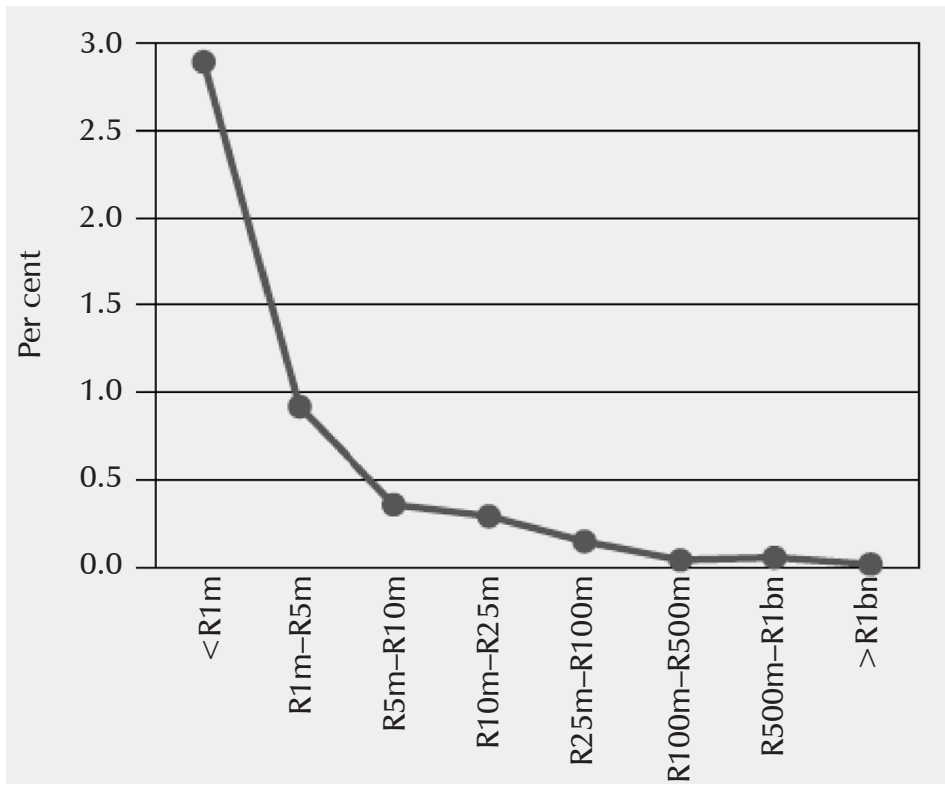

Source: (Small Business Project, 2005: 46) 
As indicated in Figure 1, the cost of tax compliance is regressive, and the annual cost of tax compliance for the small business (with an annual turnover of about $\mathrm{R} 1 \mathrm{~m}$ ), is almost 3 per cent of turnover, whereas, for the larger firms with the resources to engage tax consultants, the cost is between 0.1 to 0.5 per cent of turnover. The SMME compliance cost in South Africa was R79b (about 6.5 per cent of SA's GDP) in 2004, whereas in OECD it was less than 3 per cent (Theunissen, 2006). It takes about 350 hours (almost 9 standard working weekdays) a year for a medium-sized firm to prepare, file and pay taxes in South Africa, a much higher figure compared with that in the U.K. (105 hours) and Botswana (140 hours) (World Bank, 2007).

\section{Regulation and laws}

Freedom to conduct their own affairs and to be their own boss is one of the reasons why many people enter self-employment. However, this freedom is partially eroded as entrepreneurs become subservient to customer needs and they have to endure many laws and regulations. International evidence suggests that the regulatory environment can be a major hurdle to the survival and growth of small and new businesses. In Africa, entrepreneurs face greater regulatory hurdles than in any other region. As the costs of doing business in Africa are prohibitive because of burdensome laws and regulations, difficulties in securing property rights, ineffective courts, weak institutions and infrastructure, more reform is needed there. Some African countries, like Rwanda, Mauritius, Botswana, Namibia and Nigeria, which have made progress in introducing reforms to their business environment, are now registering high rates of economic expansion. Although the benefits of a less regulated environment are handsome, countries in Sub-Saharan Africa had the lowest business environment reform intensity among other groups of countries (World Bank, 2006).

According to the World Bank, regulatory reforms in developing countries could add as much as 1.4 per cent to average annual GDP growth in these countries (Orford et al., 2004: 51). Excessive red tape compliance costs have the potential to make firms behave in ways that could damage South Africa's overall social and economic prospects (Small Business Project, 2005: 33). Although South Africa's regulatory environment compares favourably with that of other developing countries, there is scope for further simplifying regulations and procedures.

\section{Crime}

Crime is a costly burden to individuals and firms, worryingly more so in South Africa, with "official" unemployment close to 30 per cent. Crime affects business directly, with the theft of property and money, and indirectly in reduced business confidence, loss of investment, emigration and the steady erosion of the foundations upon which the economy is built (BAC, 2006: 1). About 29 per cent of the respondents in the 2004 Investment Climate Survey rated crime as a major or very severe problem in South Africa (World Bank, 2006). Direct losses due to crime and the cost of security were equal to about 1.1 per cent of sales, a figure that is much higher than in many middle-income countries (Investment Climate Survey, 2004: 12). Security costs account for about two-thirds of the cost of crime, while direct losses account for the remaining one third.

A Nedcor-sponsored study estimated that crime cost South Africa at least R31 billion in 1995. The figure is undoubtedly much higher now, as most South Africans think crime and corruption are still prevalent in every facet of government and business in South Africa. The crime statistics released by government in June 2008, for the period April 2007-March 2008, indicate that the number of reported murder cases in South Africa was 18487 (giving a rate of 38.6 per 100000 of the population, apparently one of the highest in the world). Nationally, the crime rate for business burglary over the same period was 131.7 (62 995 cases), 497.1 for house burglary (237 853 cases) and 247.3 for aggravated robbery (118 312 cases) (Natal Witness, 1/7/2008). In the KZN province, home robbery, the most-feared crime, increased from 2667 to 3480 cases (30 per cent), while business robbery increased from 997 cases to 1923 (92 per cent) over the same period (Natal Witness, 1/7/08). Crime, together with 
corruption, constitutes a serious obstacle to doing business and adds a transaction cost (Mauro, 1995). Crime hinders entrepreneurial activity, viability and profitability of firms and slows down business development and growth of the economy. A recent study commissioned by the Presidency confirms this: over half of South Africa's small businesses have been recent victims of crime this year (2008), while about a quarter were reluctant to expand or employ more labour; they could lose at least a fifth of their annual turnover to crime through direct and indirect costs (Benjamin, 2008).

\section{3}

\section{Research objectives}

- To evaluate the external environmental conditions that favour or constrain entrepreneurship and small business development in the Pietermaritzburg region;

- To evaluate the internal environmental conditions that favour or constrain entrepreneurship and small business development in the Pietermaritzburg region.

The external factors in this study include the economy, regulations, crime, taxation, competition and technology. The internal factors include finance, labour, cash flows and managerial issues.

\section{4 \\ Research design}

This study uses the survey method to establish a relationship between entrepreneurs' perception of the business environment (internal and external) and enterprise growth in Pietermaritzburg. The database of VAT registered SMMEs, obtained from the Pietermaritzburg Chamber of Commerce, was used to draw a sample of 150 firms. These formal-sector enterprises comply with the required regulations and are therefore well positioned to express their experiences of real constraints to their development. The firms were randomly chosen. Relevant data was gathered by means of a questionnaire. The Likert-type scale consisting of a five-point scale was used. The scale point descriptions to the questions were: strongly disagree, disagree, neutral, agree and strongly agree. The questionnaire was initially pre-tested on a subsample of 10 firms.

Questions elicited information on issues external to the firm, such as the economy, laws and regulations, crime, taxation, competition and technology, and on internal issues, such as finance, managerial skills, staff, cash flow, financial understanding, transport, the nature of activity engaged in and the demographic profile of the entrepreneurs. The subjects consisted of 90 males and 60 females; of whom 46.9 per cent were Indians, 21 per cent Whites, 21 per cent Blacks, the remainder being Coloureds. They were engaged in diverse activities; 30.6 per cent in the retailing sector, 10 per cent in manufacturing, 30.6 per cent in service ventures while the remainder were in transport, construction, food franchise, travel and tourism. As far as their educational background was concerned 38.1 per cent had high school education, 18.8 per cent had a vocational education, 30.6 per cent had university degrees and 10 per cent had post-graduate qualifications.

Factor analysis and univariate analysis were used to determine whether the internal or external factors constrained the growth of the business. Reliability testing was done on a set of the questions for internal consistency using the Cronbach alpha, as they have the same scales. Ideally, the Cronbach alpha coefficient should be above 0.7 (Field, 2003). In the current study, the Cronbach alpha value obtained was 0.8687 .

\section{5}

\section{Results}

The results relating to the perceived internal and external constraints to business development are described below in two stages. Initially, the results will deal with descriptive findings largely by means of histograms, and thereafter the factor analyses results will be presented. 
Figure 2

External environmental factors

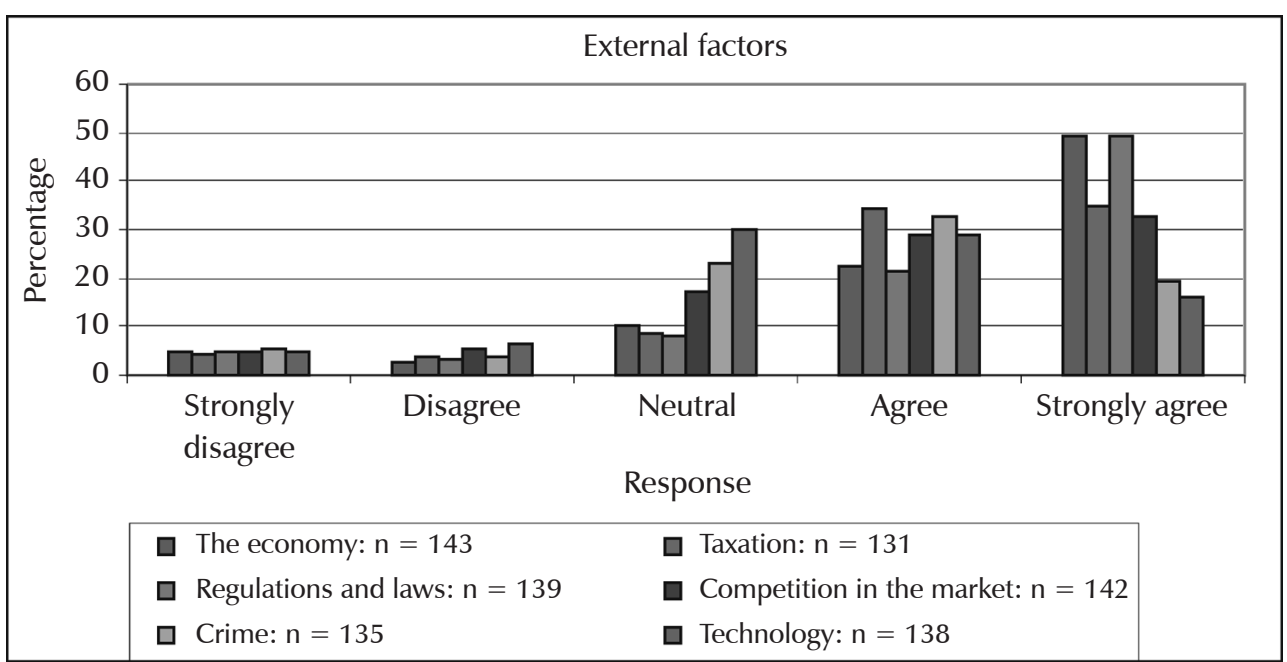

About 71 per cent of the surveyed businesses (Figure 2) felt that adverse conditions in the economy are an inhibitory growth factor. The majority of the respondents (69 per cent) agreed or strongly agreed that taxation was a constraint to the growth of their business. Another 71 per cent perceived that regulation and laws are a constraint to the growth of their business. According to Von Broembsen et al. (2005: 33), the growth potential of South African enterprises would be enormous if they were able to apply the latest technologies to their products and services. However, many small ventures find new technology inaccessible, owing to the cost involved or to a lack of knowledge and experience. Of the surveyed respondents (Figure 2), 45 per cent viewed technology as a constraint, while 30 per cent remained neutral.

A business faces competition from different local and international sources. These are brand competition from marketers of directly similar products, or substitute products that satisfy the same need and competition for the customers' limited buying power (Perrault \& McCarthy, 2002: 99). Competition can severely constrain the growth of a business, unless a firm has effective mechanisms like overall cost leadership, differentiation and focus strategies (Porter, 1985). In Pietermaritzburg, 61 per cent (Figure 2) of the respondents perceived competition, including cheap imports, as a constraint to business growth. Over half of respondents perceived crime in Pietermaritzburg (52 per cent) as a constraint to business.

Regarding finance as an internal factor, about 11 per cent of the respondents felt that obtaining finance was not a problem. About 37 per cent were neutral in their response. However, about 35 per cent (Figure 3 ) of the respondents felt that obtaining finance to grow their businesses was a major constraint. 
Figure 3

Internal factors

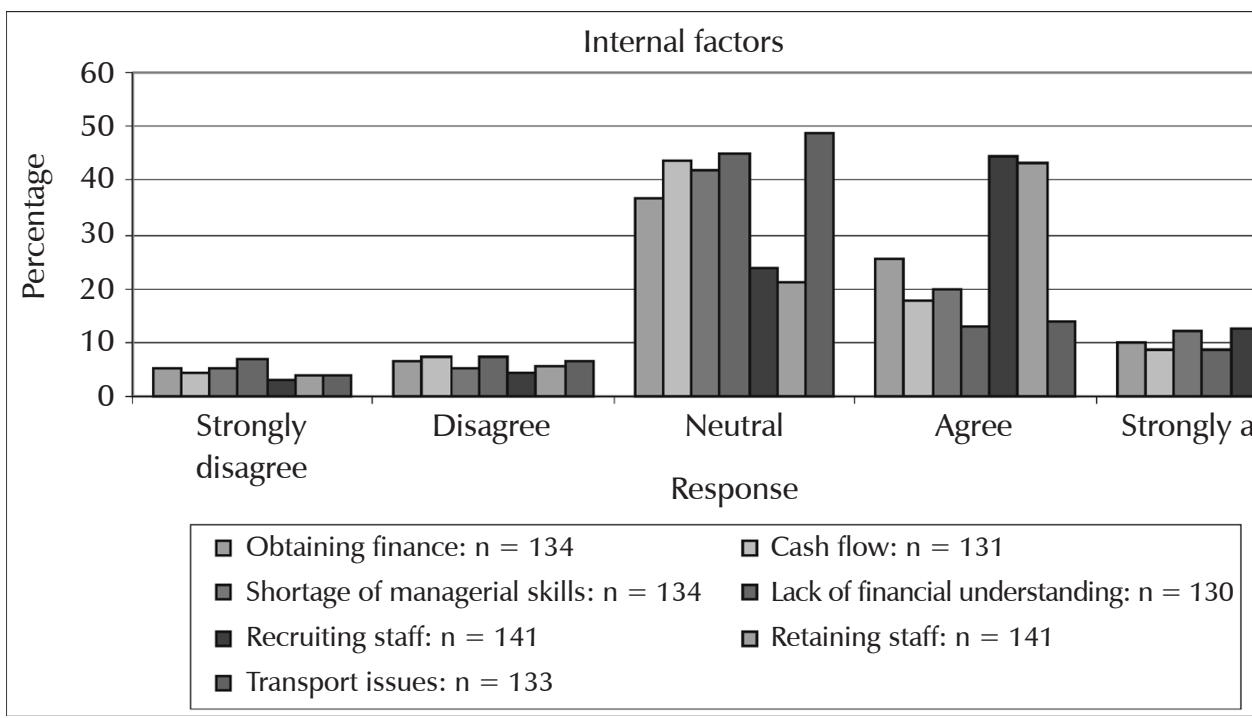

Although the modal response to the question on cash flow (43.8 per cent) was neutral, only 26 per cent of respondents perceived cash flow to be an obstacle to their businesses.

Skills in planning, organising, leading and controlling are imperative for business development. In situations where these skills are lacking, entrepreneurs can hire consultant services to assist their firms. In this study, 41.9 per cent of the respondents remained neutral, while 31.9 per cent agreed that shortage of managerial skills or business expertise was a constraint to business growth. At times, businesspersons do not understand the practice of good record-keeping. As far as the question of financial understanding was concerned, the modal response was neutral (45 per cent), and about 22 per cent agreed that a lack of financial understanding hinders growth of the business (Figure 3).

As a business grows, recruitment of staff requires more time and attention, as suitably qualified personnel have to perform specific functions. Of the surveyed businesses, 57 per cent felt that recruiting staff and another 58 per cent indicated that retaining staff were constraints to business growth. Constantlyrising fuel prices place a heavy cost burden on businesses and individuals. About half of the respondents (48.8 per cent) gave a neutral response to the transport question. However, about a quarter (24 per cent) thought transport issues were constraints to business in Pietermaritzburg.

\section{Taxes that constrain growth}

The small business entrepreneur has to comply with numerous taxes, imposing a heavy burden on the owner in terms of finance, administration, paperwork and time. The taxes examined in this study were VAT, income tax, the Unemployment Insurance Fund (UIF) and the Skills Development Levy. The majority (71 per cent) agreed that VAT and income tax were constraints to business growth (Figure 4). The tax rate for companies was reduced from 29 per cent to 28 per cent, with effect from April 2008. 
Figure 4

Taxes that constrain growth

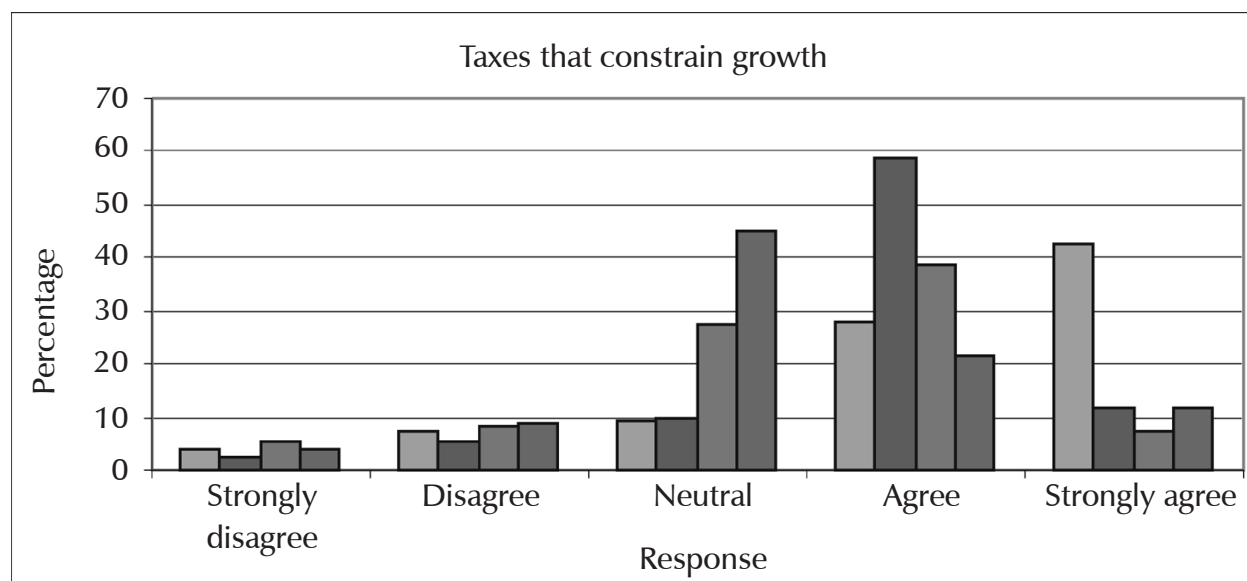

$\square$ VAT: $\mathrm{n}=146 \square$ Income tax: $\mathrm{n}=142 \quad \square$ U.I.F: $\mathrm{n}=140 \square$ Skills development levy: $\mathrm{n}=145$

Small business corporations (namely corporations with an annual turnover of less than R10 million and which meet certain specified requirements) are taxed at the rate of 0 per cent on the first $\mathrm{R} 40,000$ of taxable income, at 10 per cent for income between R40,001 and R300,00, and at 29 per cent for amounts above R300,000. A tax amnesty (expired June 2007) was granted to small businesses with an annual turnover of less than R10 million.

The Skills Development Levies Act (No 9 of 1999) imposes a 1 per cent levy based on payroll exceeding R500, 000 for skills development. Depending on the extent of appropriate training for the staff, a proportion of this levy may be claimed back. About a third of the respondents indicated that the skills development levy is a constraint to the growth of their business, though 45 per cent of respondents remained neutral. However, about 40 per cent of respondents agreed or felt strongly that UIF is a constraint to business growth.

\section{The impact of taxation on the business}

Taxes affect businesses in various ways. About 80 per cent of the respondents felt that it took too much time and too many resources to sort out their fiscal affairs (Figure 5).

Over 80 per cent agreed that the time taken in keeping records and the paperwork involved in completing tax returns were excessive. However, there may be some relief, as the tax form was simplified in 2007. Over 55 per cent of respondents stated that paying tax impacts adversely on the cash flow of the business; this money could be used for business investment. About 75 per cent thought penalties for late payments were excessive. Competition is healthy, as it keeps firms 'on their toes', but firms that may be operating informally may not be paying taxes and thus become a source of competition for formal-sector firms. A third of the respondents remained neutral, while 50 per cent agreed that competition from local firms and imports affected them.

\section{Crime and its effects}

The study shows that crime makes a seriously adverse impact on business. Almost 90 per cent of respondents indicated that crime was a large or fairly large problem. Burglaries (almost 25 per cent) were the most common, followed by theft by staff and others (just over 20 per cent). Arson was the least experienced type of crime (about 5 per cent).

Losses due to crime in South Africa amounted to R2, 272 million (Investment Climate Survey, 2004). Crime is a constraint to business growth in a number of different ways. 


\section{Figure 5}

The impact of taxation on business growth

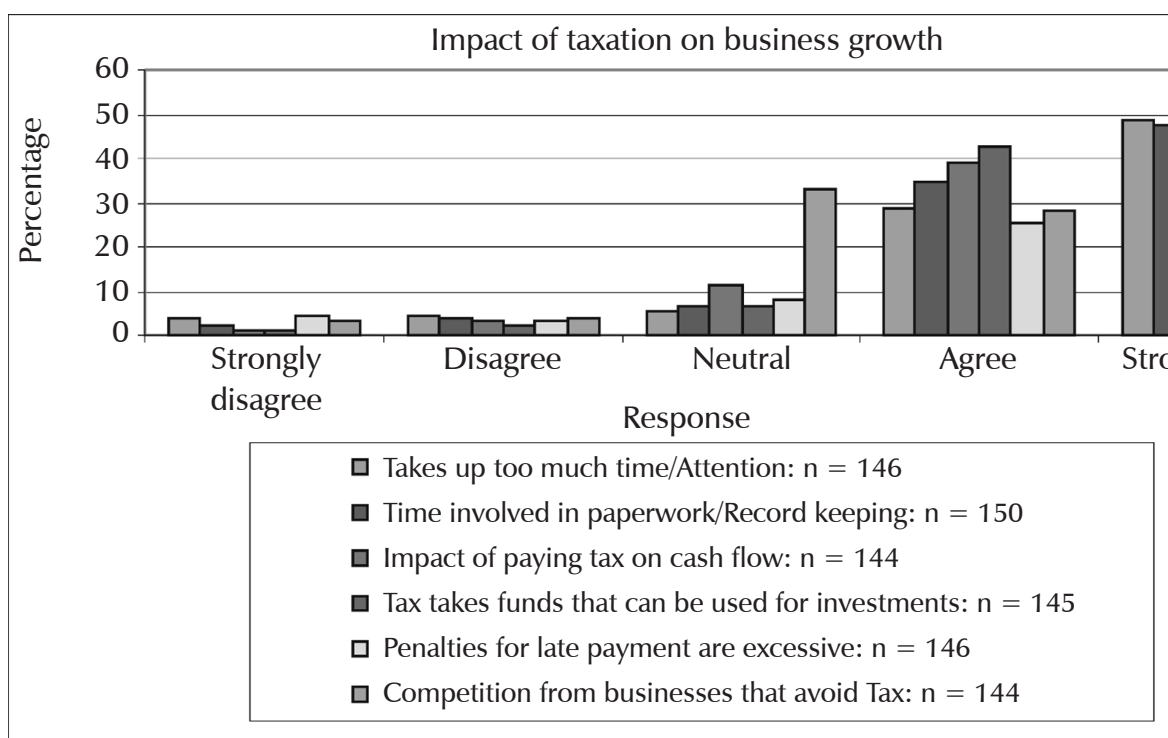

\section{Figure 6}

Effects of crime on business growth

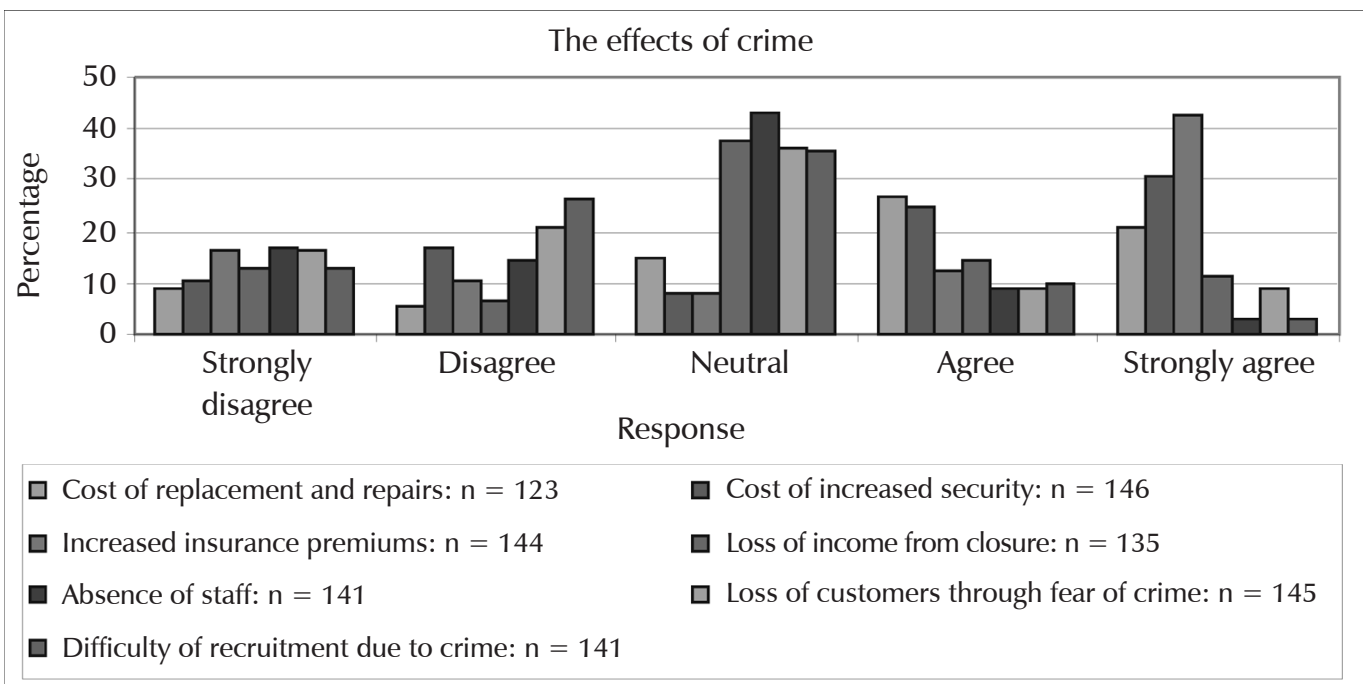

Of the surveyed entrepreneurs, 47 per cent stated that stolen stock and repairs to damaged windows, doors and locks constituted a heavy cost (Figure 6). Over 50 per cent had had to install or upgrade alarm systems and employ additional security guards to combat crime. Over half (55 per cent) stated that their insurance premiums had increased as a result of their being victims of crime. Another 25 per cent reported that that they had suffered loss of income because of business closure on account of crime, while another 11 per cent stated that they suffered 
from staff absence. Violent crimes and armed robberies traumatised workers to such an extent that long periods of rest and counselling were needed to remedy the situation. This resulted in staff absenteeism and additional temporary staff had to be hired. Such a situation could affect productivity as well as cash flow. Businesses located in areas that are constantly targeted by criminals experience loss of customers and declining sales. Customers may avoid such firms for fear of being mugged or robbed. Over a third of respondents remained neutral to this, 36 per cent disagreed and only 17 per cent agreed that loss of customers through fear of crime constrained growth (Figure 6). Further, if the business is in a high-risk, crime-prone location, the recruitment of workers can be problematic because of the fear of attack. Only 13 per cent of the respondents agreed with this question on loss of customers through fear of crime, 35 per cent remained neutral and almost 40 per cent of respondents disagreed. Overall, crimes make risk-taking a very expensive and discouraging activity, with high opportunity costs to the individual, society and economy, in terms of security, loss of income, employment and trade.

\section{Factor analysis}

So far we have presented the descriptive results. The overwhelming majority of the business persons surveyed perceived taxation, the economy, crime, laws and regulations to be major external growth inhibiting factors, while just under half ( 45 per cent) perceived technology to be a constraint. As far as internal environmental conditions were concerned, obtaining finance, the shortage of managerial skills, cash flow and transport issues were identified as growth-inhibiting factors, but these were perceived as problems by less than 50 per cent of the respondents. Some respondents were "neutral" in their assessments of these constraints. However, recruitment and retention of staff were identified as major sources of internal constraint by about 58 per cent of the entrepreneurs surveyed.

These factors do not affect business growth uniformly. Some are more prominent than others. If we are to secure the "optimal" growth of the SMME sector, it is important to have some understanding of whether the perceived internal factors have a greater bearing on inhibiting growth than the external factors. Such information could help policymakers and business persons to address limitations on SMME development. For this reason, factor analysis was undertaken in this study to reduce the initial set of internal and external factors to a smaller, more manageable set or cluster, and to gain clearer insights into whether internal factors had a greater bearing than the external factors in adequately explaining the growth constraints. The Principal Components method was used with varimax rotation. The results of total variance in growth constraints are summarised in Table 1 below.

Table 1

Total variance explained

\begin{tabular}{|c|c|c|c|c|c|c|c|c|c|}
\hline \multirow[t]{2}{*}{$\begin{array}{l}\text { Com- } \\
\text { ponent }\end{array}$} & \multicolumn{3}{|c|}{ Initial eigenvalues } & \multicolumn{3}{|c|}{$\begin{array}{l}\text { Extraction sums of squared } \\
\text { loadings }\end{array}$} & \multicolumn{3}{|c|}{$\begin{array}{c}\text { Rotation sums of squared } \\
\text { loadings }\end{array}$} \\
\hline & Total & $\begin{array}{c}\% \text { of } \\
\text { variance }\end{array}$ & $\begin{array}{l}\text { Cumu- } \\
\text { lative \% }\end{array}$ & Total & $\begin{array}{c}\% \text { of } \\
\text { variance }\end{array}$ & $\begin{array}{l}\text { Cumu- } \\
\text { lative \% }\end{array}$ & Total & $\begin{array}{c}\% \text { of } \\
\text { variance }\end{array}$ & $\begin{array}{l}\text { Cumu- } \\
\text { lative \% }\end{array}$ \\
\hline 1 & 4.701 & 36.159 & 36.159 & 4.701 & 36.159 & 36.159 & 3.170 & 24.382 & 24.382 \\
\hline 2 & 1.663 & 12.794 & 48.953 & 1.663 & 12.794 & 48.953 & 2.681 & 20.623 & 45.005 \\
\hline 3 & 1.333 & 10.257 & 59.210 & 1.333 & 10.257 & 59.210 & 1.847 & 14.205 & 59.210 \\
\hline 4 & .996 & 7.659 & 66.869 & & & & & & \\
\hline 5 & .911 & 7.005 & 73.874 & & & & & & \\
\hline
\end{tabular}




\begin{tabular}{|c|r|r|c|l|l|l|l|l|l|}
\hline 6 & .724 & 5.565 & 79.439 & & & & & & \\
\hline 7 & .605 & 4.657 & 84.096 & & & & & & \\
\hline 8 & .514 & 3.953 & 88.049 & & & & & & \\
\hline 9 & .480 & 3.692 & 91.741 & & & & & & \\
\hline 10 & .393 & 3.022 & 94.763 & & & & & & \\
\hline 11 & .301 & 2.316 & 97.079 & & & & & & \\
\hline 12 & .215 & 1.654 & 98.733 & & & & & & \\
\hline 13 & .165 & 1.267 & 100.000 & & & & & & \\
\hline
\end{tabular}

Extraction Method: Principal component analysis

In the above table, the cumulative variance shows that three clusters jointly explain 59.210 per cent of the total variance in growth constraints. Further, all three clusters have Eigen values over 1 . The variables (1 to 13 ), as constraints to growth under consideration, ranging from retaining staff to competition, and the formation of the cluster components, are presented in Table 2.

Table: 2

Rotated component matrix

\begin{tabular}{|l|c|c|c|}
\hline \multirow{2}{*}{ Variables } & \multicolumn{3}{|c|}{ Cluster components } \\
\cline { 2 - 4 } & 1 & 2 & 3 \\
\hline Retaining staff & .816 & .142 & .135 \\
\hline Recruiting staff & .810 & .011 & .047 \\
\hline Shortage of managerial skills & .653 & .510 & -.206 \\
\hline Keeping up with new technology & .626 & .209 & .169 \\
\hline Transport issues & .605 & .423 & .143 \\
\hline Cash flow & .169 & .800 & -.160 \\
\hline Obtaining finance & .296 & .780 & .075 \\
\hline Crime & -.005 & .658 & .257 \\
\hline Lack of financial understanding & .354 & .574 & .144 \\
\hline The economy & -.010 & -.042 & .813 \\
\hline Taxation & .322 & .022 & .602 \\
\hline Regulations and laws & .561 & .158 & .597 \\
\hline Competition in the market & .037 & .374 & .486 \\
\hline
\end{tabular}

The rotated loadings table has to be viewed to find out which questions are not loading at all on the factors and could therefore be eliminated from the data set and then re-run the factor analysis. Now all 13 variables are loaded in order to view the classification of the different sets of clusters.

The first set of factors is labelled "management", which consists of five items with loadings ranging from 0.605 to 0.816 (Table 2). These 
factors are: retaining staff, recruiting staff, shortage of managerial skills, keeping up with new technology and transport issues. The management set, consisting mainly of factors internal to the business, accounts for 36.159 per cent of the variance. The main loadings in this set are retaining staff and recruiting staff, with values 0.816 and 0.810 respectively. Cronbach's alpha calculated for this cluster yielded a value of 0.7278 . The three sets of factors are summarised in Table 3.

Table 3

Classification of cluster groups components and environmental factors

\begin{tabular}{|l|l|}
\hline Management factors & Environment \\
\hline Retaining staff & Internal \\
\hline Recruiting staff & Internal \\
\hline Shortage of managerial skills & Internal \\
\hline Keeping up with new technology & External \\
\hline Transport issues & Internal \\
\hline Finance factors & Internal \\
\hline Cash flow & Internal \\
\hline Obtaining finance & External \\
\hline Crime & Internal \\
\hline Lack of financial understanding & External \\
\hline Economic factors & External \\
\hline The economy & External \\
\hline Taxation & External \\
\hline Regulations and laws & \\
\hline Competition in the market & \\
\hline
\end{tabular}

The second set, presented separately in Table 3, is labelled "Finance". It consists of four factors, with loadings ranging from 0.574 to 0.800 (Table 2). This second group consists of finance-related internal factors, with the exception of crime (Table 3). Cash flow and access to finance had the highest loadings in this group, with values 0.800 and 0.780 respectively. Crime is, without doubt, an external factor. However, the negative effects of crime, such as increased costs of security, or replacement and repair costs impact internally on the finances of the business. The finance cluster accounts for 12.794 per cent of the total variance (Table 1). Cronbach's alpha calculated for factor 2 equalled 0.8251 .

The third group, consisting of four factors, has loadings ranging from 0.486 to 0.813 (Table
2). This consists of the economy, taxation, regulations and laws, and competition in the market (Table 3). The economic condition is the second highest loading factor (0.813) of all the three sets. Being largely external in nature, the third group is classified as "economic" and accounts for 10.257 per cent of variation. Factor three is reliable with a Cronbach alpha coefficient of 0.8841 .

\section{6}

\section{Discussion and recommendation}

From the above analysis, it is evident that the internal constraints (clusters 1 and 2) jointly account for almost 49 per cent of variance in growth, and factor 3 accounts for 10.257 per 
cent of the total variance. The results show that management and finance are major internal issues constraining the development of businesses. The factor analysis shows that internal constraints account jointly for almost half the variance in growth impediments. The management cluster accounted for 36.159 per cent of the variance while the finance-related cluster, again mainly internal factors with the exception of crime, accounted for 12.794 per cent of the total variance. These three principal components account jointly for almost 60 per cent of the variance in environmental growth constraints. The results of this study concur to a great extent with the findings of other studies, such as those of the World Bank, Trade and Industrial Policy Strategies (TIPS), GEM and the one more recently commissioned by the South African Presidency. These all identify broadly similar results, in that three sets of constraints affect SMME development. These relate to management and labour skills, finance and external environment, particularly crime in South Africa. The World Bank identified crime and labour issues as the top two major constraints, followed by a lack of confidence in courts to uphold property rights, taxes, policy uncertainty and finance respectively as other major environmental constraints to firms and entrepreneurs, to investment and to job creation (World Bank, 2006).

Firms operate in competitive and changing environments. As the external environmental situation changes, SMMEs too have to adapt to change in order to survive. The external environment of the firm would identify opportunities and threats, while the internal environment would reflect resource strengths and weaknesses of the business and demonstrate the need for strategic decision making on the firm's resources to match the changing external and market needs. Businesses that are likely to survive, develop and achieve ongoing success are those with the competencies for dealing with changes in the external environment and in reinventing themselves. These can be possible with appropriate internal strategies passionately driven by the SMME entrepreneurs.

Penrose (1995) maintains that, when examining enterprise development and growth, the emphasis should be on the internal resource conditions of the firm (management and capital), which have also been perceived as important by the entrepreneurs in this study. Venture development is therefore largely driven by enterprising management of the firm. As management tries to make the best use of resources available, a dynamic interacting process occurs that encourages continuous development, but limits the rate of development if the external environmental forces are unfriendly to enterprise (Penrose, 1995: 7).

The business entrepreneur has little control over external factors, among which crime, in its various forms, features prominently as a serious obstacle to business development and human safety. Constant environmental scanning can ensure alertness to both favourable and adverse external conditions. To a certain degree, the internal factors are within the control of the entrepreneurs and these are areas in which improvements can be made with pro-active strategies. They should therefore enhance their managerial and entrepreneurial skills in weaker areas, especially when it comes to cash flow, keeping records or understanding financial statements and use of technology. This would include the recruitment and retention of appropriate staff, with the possible provision of education and training. If staff recruitment is a problem, then the question of education and training of workers deserves attention to overcome skills constraints. Provision of finance is certainly necessary, but is not a condition per se. There is no point in providing large financial sums for advancing enterprise development if someone does not know how to use it to generate wealth and create employment opportunities. The ability to manage finance effectively is crucial.

Taxation and regulations were also seen as major constraints to growth for various reasons, ranging from consuming too much managerial time in keeping records to the adverse impact on cash flow and increasing transaction costs. The third group factor to emerge from the factor analysis was comprised of the "economy, taxation, regulation and laws" and "competition in the market". These sets are external in nature, and account for about 10 per cent of variation 
in growth. Firms are unlikely to develop rapidly in an environment where there are too many external governmental pressures in the form of regulatory procedures, intrusive laws, and fiscal as well as administrative burdens that affect the structure, conduct and profitability of business. For South Africa to accelerate its economic and SMME development, it has to create a supportive business investment climate and address the external environmental conditions.

Recruitment and retention of staff and the high crime rates prevailing in the country were also identified as major problems by the majority of the businesses. The resulting burden is driving up the transaction costs of doing business. Also, the current difficult labour legislation in South Africa, along with the rigidity of its employment index at 52 (0 is less rigid) makes it difficult for firms to hire and fire workers (World Bank, 2006). After all, one of the tenets of economic freedom is that individuals should be free to sell their entitlements and use their time and resources as they wish (Sen, 1999). However, this is complicated by the high levels of crime and labour legislation. Accordingly, introducing greater labour market flexibility seems important for business development and employment creation. Regulatory "red tape" procedures ought to be cut down, while the problem of crime in its various manifestations should be urgently addressed if SMMEs are to flourish in South Africa. For every small business that closes because of crime at least six jobs are lost (Geldenhuys, 2008). Entrepreneurship thrives in a market-oriented environment, in which encouragement comes from respect for law and order, property rights, safety and security, good governance, improving education, high levels of investment and steady gains in productivity (Mahadea, 2003: 46), and not when certain self-interested policy-makers dictate the terms. Unless a propitious environment is created, the entrepreneurial class and SMMEs will be incapable of realising their development potential as a major engine for job creation and poverty alleviation, as well as acting as a catalyst for economic growth.

\subsection{Limitations and future research}

The findings of this study clearly provide a "snapshot" of the internal and external environmental factors that are perceived as having a significant influence on SMME growth and development. Although the findings tend to confirm the results of other similar studies in the field of entrepreneurship, the results are possibly limited as to their generalisation, as they were based on a sample size of 150 firms in a specific province and at a specific point in time. It is therefore suggested that future research on environmental constraints to SMME growth and development use longitudinal approaches and cover other provinces as well with a larger sample.

Businesses do not lack growth simply on the basis of an unfavourable investment or external economic climate. No business was ever known to have started on its own. Many of the limitations reside within the firm itself and the quality of entrepreneurship, as well as leadership inputs by its manager-owner. The potential to grow depends on certain traits, such as a high level of motivation and innovative tendencies, and these vary across cultures, gender and regions. Evidently, this is a question of ethnographic, geographical and psychological traits relating to entrepreneurship, which the study did not examine. These limitations present future research opportunities to identify critical traits and environmental influences, as they relate not only to SMME business development but also to their impact on poverty reduction, enhancing exports, combating crime and corruption, and creating much needed sustainable employment in the country.

\section{7}

\section{Conclusion}

The above results show clearly that the management factor has the greatest variance in growth, followed by finance and then the external economic set. The internal factors therefore comprise as great a burden as the external factors on the growth potentials of the business, although their "intensity" can vary. This leads one to suggest that, while there is no best 
strategy for all businesses, policy must limit the internal and external environmental factors that prevent firms from developing, and instead must encourage the forces that favour entrepreneurial activity. Provision of financial support to SMMEs is as important as augmenting their absorptive capacity to handle finance, as well as strengthening the general and managerial skills of the entrepreneurs and labour. Firms driven by opportunity entrepreneurs are generally known to make significant contributions to economic growth, job creation, income generation and the wealth-creation process in an economy. These are the entrepreneurs who are more likely to overcome internal growth constraints and adapt the internal aspects of the firm to fit the changing external environment. However, this does not mean that the needs of necessity entrepreneurship are to be overlooked, although the latter has low potential for employment creation in South Africa.

On the external front, addressing the problems of both crime in its various manifestations and the perceived high levels of taxation and regulation are critical for SMME development in South Africa. The role of the state is fundamental to making the broad environment a safer and better place for individuals to live, work and conduct businesses with attractive prospects of ethically earning adequate returns. The ideal habitat for optimal development of entrepreneurship is a safer and supportive environment with equal opportunities, minimum legislation and regulation, and effective policy interventions, as well as visionary leadership.

\section{Acknowledgement}

The authors would like to thank two anonymous referees and Professor SF Koch for their helpful comments on this paper.

\section{References}

1 B A C (2006) "Business against crime": Executive Brief. www.bac.bac.co.za.

2 BENJAMIN, C. (2008) "South Africa: Crime crippling small business", Business Day, 17 July.

3 CASSON, M.C. (2003) The Entrepreneur: An Economic Theory, Edward Elgar: London.
4 CROMIE, S. (2000) "Assessing entrepreneurial inclinations: Some approaches and empirical evidence, European Journal of Work and Organisational Psychology, 9: 7-30.

5 FIELD, A. (2003) Discovering Statistics, SAGE Publications: London.

6 FRY, F.L.; STONER, C.R. \& HATTWICK, R.E. (2001) "Business: An Integrative Approach, McGraw-Hill: Boston.

7 GELDENHUYS, H. (2008) "Armed attacks in the rest of the country rocket as crime spreads beyond Gauteng”, Sunday Times, 13/1/08.

8 GNYAWALI, D.R. \& FOGEL, D.S. (1994)

"Environments for entrepreneurship development: Key dimensions and research implications", Entrepreneurship Theory and Practice (Summer): 43-62.

9 MAAS, G. \& HERRINGTON, M. (2006) "Global entrepreneurship monitor-South African report", www.GEM SouthAfrica2006.pdf

10 MAAS, G. \& HERRINGTON, M. (2007)

"Entrepreneurship: Low levels threaten growth", Management Today, 23 (2)

11 MAHADEA, D. (1997) "Financial constraints on small business entrepreneurs", Acta Academia, 29 (1): 70-89.

12 MAHADEA, D. (2001) "Similarities and differences between male and female entrepreneurial attributes in manufacturing firms in the Transkei", Development Southern Africa, 18 (2): 189-200.

13 MAHADEA, D. (2003) "Employment and growth in South Africa: Hope or despair?" South African Journal of Economics, 71(1): 21-48.

14 MARSHALL, A. (1891) Principles of Economics, Macmillan: London.

15 MAURO, P. (1995) “Corruption and growth", Quarterly Journal of Economics, 110 (3): 681-712.

16 MOSS, T. (2007) African Development, Lynne Reiner: London.

17 Natal Witness (2008) KZN home invasion shock, 1 July.

18 NIEMAN, G; HOUGH, J. \& NIEUWENHUIZEN, C (2003) Entrepreneurship: A South African Perspective, Van Schaik: Pretoria.

19 NORTH, D. (1994) "Economic performance through time", American Economic Review, June, 359-68.

20 NTSIKA (2000) The State of Small Business in South Africa, Ntsika Enterprise Promotion Agency, Pretoria.

21 ORFORD, J.; WOOD, E.; FISHER, C.; HERRINGTON, M. \& SEGAL, N. (2003)

"Global entrepreneurship monitor", South African 
Executive Report. Graduate School of Business, UCT.

22 ORFORD, J.; GOLDSTUCK, A.; SHAY, D.; WOOD, E.; HERRINGTON, M. \& HUDSON, J. (2004) "Global entrepreneurship monitor", South African Executive Report, Graduate School of Business, UCT.

23 PENROSE, E. (1995) The Growth of the Firm, Basil Blackwell: Oxford.

24 PORTER, M. (1985) Competitive Advantage, Free Press: New York.

25 SCHUMPETER, A. (1942) Capitalism, Socialism and Democracy, NY Harper \& Row: New York.

26 SEN, A.K (1999) Development as Freedom, Knorf: New York

27 SMALL BUSINESS PROJECT (2005)

"Counting the cost of red tape for business in South Africa”, Main Report, Riaan de Villiers \& Associates, Johannesburg.

28 SARB (2008) South African Reserve Bank Quarterly Bulletin, 248 (June), Pretoria.

29 STOREY, D.J. (1995) Understanding the Small Business Sector, Routledge: London.

30 THEUNISSEN, G. (2006) "SMME compliance cost", Finance Week (19/10/06)
31 TIPS (2003) "The SMME economy in South Africa”, Tips Workshop, (10 November)

Johannesburg.

32 VAN DER MERWE, M. (2003) "The entrepreneur", in Entrepreneurship: A South African Perspective, Nieman, G., Hough, J. \& Nieuwenhuizen, (eds.) Pretoria: Van Schaik, $27-$ 44.

33 VON BROEMBSEN; WOOD, M.; HERRINGTON; SHAY, M. \& SHEPPERS, R. (2005) "Global entrepreneurship monitor", South African Report, GSB, UCT.

34 WORLD BANK (2005) Doing Business in 2005, World Bank, International Finance Corporation, Oxford University Press, Washington, D.C.

35 WORLD BANK (2004) "South African investment climate survey", Investment climate survey, www.worldbank.org.

36 WORLD BANK (2006) World Bank Indicators, Washington D.C.

37 WORLD BANK (2007) Doing Business, 2007, World Bank, Washington D.C. 